\title{
SOLVING TASKS OF VESSEL COLLISION AVOIDANCE AND MANEUVERING DURING DESIGNING DECISION SUPPORT SYSTEMS OF THE NAVIGATOR
}

\section{ВИРІШЕННЯ ЗАВДАНЬ РОЗХОДЖЕННЯ \\ ТА МАНЕВРУВАННЯ СУДНА ПРИ СТВОРЕННІ СИСТЕМ ПІДТРИМКИ ПРИЙНЯТТЯ РІШЕНЬ СУДНОВОДІЯ}

\author{
Andrii Ben ${ }^{1}$ \\ Ihor Palamarchuk ${ }^{2}$
}

DOI: https://doi.org/10.30525/978-9934-588-15-0-51

Abstract. Purpose. The purpose of the work is to develop the latest conceptual approaches to the creation of decision support systems of the navigator, to determine the theoretical and methodological foundations for the construction of such systems and priority ways of their practical implementation, which will improve navigation safety. Method. In the application plan, this work is aimed at creating a software product, the application of which will allow to solve an important scientific and applied task in the field of application of information technology in navigation - improving the safety of ship management through the introduction of decision support systems of the navigator using artificial intelligence methods, in particular scenario-based approach to building a knowledge base of decision support systems for modeling interaction processes. Object. The object of the research is the decision-making processes in navigation. The peculiarity of decision-making in navigation is the need to form and make decisions in real-time, provided there is a complex cooperative interaction between the participants of the navigational situation and the availability of constant information exchange of the navigator with the technical means of ship management. Subject. The subject of the research is the newest conceptual approaches to the creation of decision support systems in navigation,

${ }^{1}$ Candidate of Technical Sciences, Assistant Professor,

Vice-rector of Research,

Kherson State Maritime Academy, Ukraine

${ }^{2}$ Postgraduate Student,

Kherson State Maritime Academy, Ukraine 
theoretical and methodological bases for the construction of such systems, taking into account the features of the movement of ships, the process of human interaction with the technical means of navigation and the requirements of International Regulations for Preventing Collisions at Sea (COLREG-72). Practical importance. During the research it was determined that in the conditions of introduction of modern information technologies in navigation and the concept of e-Navigation, the most important component of improving the safety of current navigation is the creation of decision support systems of the navigator. When creating such systems, it should be consider that the most important factor in the accidents of current navigation is the so-called "human factor", so when creating decision support systems of the navigator, special attention should be paid to the processes of interaction of the navigator with the technical means of navigation and by reducing the impact of "human factor" on ship management processes. Scientific novelty. It is shown that the perspective direction of the development of decision support system of the navigator is the application of artificial intelligence methods, in particular scenario-based approach to building the knowledge base of decision support systems for modeling interaction processes. In modern conditions the implementation of decision support systems of the navigator is capable to reduce substantially accidents at current navigation, first of all by increase of efficiency of functioning of ergatic system "man - technical means of navigation" and comprehensive introduction of achievements of modern information technologies in processes of ship management. Results. Theoretical and methodological principles of construction of the decision support system of the navigator have been developed, taking into account the peculiarities of the motion of vessels, the process of human interaction with the technical means of navigation, and the requirements of the COLREG-72. Created decision support system of the navigator has advantages over existing analogues, as it allows to simultaneously solving the problems of passage and maneuvering of ships.

\section{1. Ветуп}

Розвиток сучасного судноплавства нерозривно пов'язаний із широким впровадженням нових інформаційних технологій, стрімким розвитком засобів супутникової навігації та електронних картографічних інформаційних та навігаційних систем. Існуючі на сьогодні розробки 
в галузі створення інформаційних систем управління рухом суден спрямовані в основному на розрахунок безпечних зон руху і не враховують впливу так званого «людського чинника» на процеси сприйняття інформації судноводієм, формування та прийняття ним рішень, а також загальної взаємодії всіх учасників навігаційної ситуації.

Як показує аналіз причин виникнення аварій на морі, головним їх фактором є і залишається, так званий, людський фактор (близько 85\% усіх випадків) - більшість навігаційних аварій відбувається не через відмову технічних засобів навігації або управління рухом судна, а через неготовність судноводіїв своєчасно приймати рішення відповідно до ситуації, яка складається [1, с. 17; 2, с. 171]. Зниження впливу людського фактору на рівень аварійності на морі є актуальною науково-практичною проблемою сьогодення, яку необхідно вирішувати в розрізі оптимізації взаємодії судноводія з сучасними технічними засобами.

Іншою важливою проблемою сьогодення $є$ підвищення точності дотримання суднами планованої траєкторії руху, що обумовлено потребою подальшої розробки ресурсів континентального шельфу в зв'язку із необхідністю забезпечення енергетичної безпеки України.

Таким чином на поточний момент існує нагальна проблема в створенні сучасних систем підтримки прийняття рішень (СППР) 3 управління рухом суден, що враховують особливості процесу взаємодії людини з технічними засобами судноводіння та забезпечують прийняття нею рішень в складних навігаційних умовах та критичних ситуаціях, які здатні ефективно вирішувати значну частку питань, пов'язаних із процесами формування рішень з управління судном та зниженням впливу «людського фактору». Створення та застосування систем підтримки прийняття рішень в судноводінні набуває особливого значення в умовах інтенсивного впровадження сучасних інформаційних технологій та концепції е-navigation [3, с. 8].

\section{2. Людський елемент як фактор до створення СППР}

3 точки зору науки «судноводіння - єдиний процес, що забезпечує плавання і керування судном для досягнення поставленої мети». Відомо, що мета торгівельного, промислового, наукового та військового мореплавства різна. Однак вимоги до забезпечення безпеки мореплавства єдині, а спільне завдання судноводіння універсальне. Навіга- 
ційна безпека плавання - невід'ємна умова вирішення будь-якої задачі мореплавання, а спільне завдання судноводіння стисло формулюється так «провести судно з одного пункту в інший за заздалегідь наміченим, безпечним і найвигіднішим шляхом».

3 метою подолання негативного впливу людського фактора і запобігання можливих наслідків людських помилок в судноводінні, необхідно проводити послідовну політику вдосконалення механізмів і пристроїв, створювати в рамках інтелектуальних систем управління (ICУ) системи штучного інтелекту, орієнтовані на вирішення завдань контролю, оцінки ситуації, прийняття рішень і управління конкретними судновими об'єктами, системами і пристроями.

Значною перешкодою на шляху розв'язання цього питання стає відсутність чітких формальних моделей, які характеризують процеси взаємодії суден при розходженні. Особливо це стосується ситуації невизначеності, зокрема, коли наявні два та більше суден, а умови огляду водної акваторії $є$ недостатніми. Ключовим фактором правильного рішення такої задачі $є$ забезпечення ефективності рішень управління судном, що приймаються судноводієм. Так, чим складнішими становляться функції судноводія, тим гостріше встає необхідність у координації роботи технічних засобів та інтерпретації інформації, яка надається з їх боку судноводію.

Слід зазначити, що розробка СППР судноводія пов'язана з низкою складнощів, одна з яких - формалізація Міжнародних правил попередження зіткнення суден 1972 року (МППЗС-72) у вигляді, зручному для практичного використання в базі знань СППР.

\section{3. Вимоги до створення СППР судноводія}

Наявний досвід створення СППР в судноводінні дозволяє зробити висновок, що їх ефективне практичне використання можливо тільки в разі дотримання ряду важливих вимог, обумовлених, з одного боку, особливостями функціонування безпосередньо СППР, а 3 іншого процесами прийняття рішень в судноводінні.

Робота СППР в режимі реального часу, накладає жорсткі часові обмеження на процеси розробки та прийняття рішень і вимагає побудову сценаріїв розходження суден на весь період взаємодії. Зазначені обставини зумовлюють необхідність розробки математичних моделей, 
адекватних вимогам МППЗС-72 та придатних для опису ситуацій взаємодії суден при розходженні та прийнятті рішень з управління судном в реальному часі.

Аналіз процесів прийняття рішень судноводієм, дозволив нам виявити п’ять базових принципів, які використовуються ним на практиці:

- увага судноводія концентрується переважно не на варіантах рішення задачі розходження, а на умовах протікання процесу управління судном, які він аналізує, спираючись на свій досвід практичної діяльності;

- за сприятливих умов (невелика кількість об'єктів, добра видимість, відсутність втоми) судноводій здатний самостійно долати фактори неточності і невизначеності опису навігаційної ситуації і оперативно приймати правильне рішення на основі наявного досвіду;

- при несприятливих умовах, наявності зовнішніх впливів, втоми, судноводій вирішує завдання розходження на основі найбільш значущих, з його точки зору, факторів і системи узагальнених оцінок, не беручи до уваги багато «несуттєвих» деталей;

- аналізуючи інформацію про навігаційну ситуацію в зоні маневрування, судноводій підсвідомо оцінює динаміку навігаційних параметрів, екстраполюючи їх очікувану зміну в часі і формуючи єдину модель ії подальшого розвитку;

- в складних умовах судноводій постійно оцінює не лише динаміку розвитку подій, але й імовірність досягнення поставленої мети, яка виявляється у вигляді емоційного відчуття успіху або тривоги.

Зазначені обставини зумовлюють виникнення «людського фактора» як однієї з основних причин аварійності в судноводінні. Необхідність мінімізації його впливу шляхом використання СППР судноводія, дозволяє сформулювати основні вимоги до СППР:

- робота СППР в режимі реального часу та їі інтеграція за наявними на судні системами управління рухом;

- необхідність врахування всіх вимог МППЗС-72;

- необхідність графічного представлення сформованої ситуації, 3 візуальними позначками меж зони безпеки власного судна і динамки ї змін;

- необхідність аналізу під час прийняття рішень декількох можливих сценаріїв розходження, обумовлених цілеспрямованою поведінкою суден-цілей під час їх руху; 
- необхідність врахування впливу зовнішніх умов у зоні маневрування, зокрема гідрометеорологічних, гідрографічних факторів і навігаційних небезпек;

- врахування попереднього досвіду управління рухом судна в аналогічних умовах, якщо він мав місце.

Під час наукового дослідження також були визначені базові вимоги до моделей і алгоритмів, що застосовані під час розробки СППР судноводія:

- рух кожного з суден-учасників навігаційної ситуації розглядається з позиції цілеспрямованої поведінки, що має на меті уникнення зіткнень з іншими суднами, максимально дотримуючись при цьому вимог МППЗС-72;

- для аналізу процесу розвитку навігаційної ситуації необхідно будувати багатокрокові сценарії іiі розвитку, приймаючи до уваги динамічні моделі поведінки суден-учасників руху;

- слід враховувати, що реальний процес розходження суден проходить в умовах складної взаємодії учасників у випадку, якщо їх число більше двох, а умови видимості відрізняються від добрих;

- кількість можливих сценаріїв розвитку навігаційних ситуацій, які аналізуються СППР достатньо велика, і їх число необхідно скорочувати, виходячи як з обмежень МППЗС-72, так і динаміки змін ключових параметрів руху суден (ліній відносного руху (ЛВР), пеленгів і швидкостей).

- необхідно враховувати і накопичувати в СППР інформацію щодо попереднього досвіду управління рухом судна в аналогічних умовах, якщо такий мав місце.

\section{4. Застосування МППЗС-72 в СППР судноводія}

МППЗС-72 є основним нормативним документом, що регламентує процеси розходження суден, і їх формалізацію у вигляді, придатному для використання в СППР судноводія та є актуальною науковою і практичною задачею. Істотним недоліком МППЗС-72 є те, що правила регламентують дії судноводія тільки для випадків бінарної взаємодії і не розглядають ситуації одночасного розходження декількох суден. Крім того, правила самі по собі є джерелом невизначеності в описі ситуації розходження зважаючи на неоднозначність трактування деяких приписів. 
Оскільки МППЗС-72 регламентують попарну взаємодію суден, при формуванні сценаріїв розвитку поточної ситуації в СППР доцільно розглядати саме такий вид взаємодії, приймаючи, однак, при цьому до уваги той факт, що судна взаємодіють не тільки з власним судном, але й один з одним. Вибір пар суден, взаємодія яких аналізується СППР i для яких формуються сценарії, здійснюється відповідно рівня їх небезпеки один для одного. Очевидно, що число розглянутих взаємодіючих пар суден для випадку суден у зоні розходження буде дорівнювати числу сполучень $C_{N}^{2}$ :

$$
C_{N}^{2}=\frac{N !}{(N-2) ! 2 !}
$$

Ця величина на практиці вкрай рідко перевищує значення 190 (що відповідає 20-ти суднам в зоні розходження), а, для більшості розглянутих ситуацій, знаходиться в діапазоні (2-7 взаємодіючих суден відповідно). Зазначений порядок величини $C_{N}^{2}$ хоча й унеможливлює «програвання» всіх можливих варіантів взаємодій безпосередньо зусиллями судноводія, як це зазначається в роботі [4, с. 70], тим не менш, не є перешкодою для здійснення такої операції сучасними засобами обчислювальної техніки в режимі реального часу, враховуючи ту обставину, що реальне значення величини $C_{N}^{2}$ може бути додатково суттєво зменшено шляхом введення попередньої класифікації суден за ступенем їх небезпеки один для одного. Оцінка навігаційної ситуації в СППР і побудова можливих сценаріїв її подальшого розвитку здійснюється шляхом формування та аналізу логічних правил, представлених у вигляді фрейм-структур.

Загальний алгоритм роботи СППР щодо запобігання зіткнень суден має наступний вигляд (рис. 1).

- ідентифікація суден, що знаходяться в зоні можливого зіткнення;

- моніторинг параметрів руху суден та динаміки їх зміни;

- оцінка похибки одержуваних параметрів руху;

- класифікація суден за ступенем небезпеки;

- визначення пар взаємодіючих суден, для яких формуються можливі сценарії руху;

- визначення областей взаємних обов'язків у відповідності із МППЗС-72 і меж зони безпеки власного судна;

- формування множини можливих сценаріїв (стратегій) руху суден; 
- визначення стратегій руху, що відповідають заданим критеріям безпеки;

- вироблення можливих альтернатив з управління судном і надання їх судноводію.

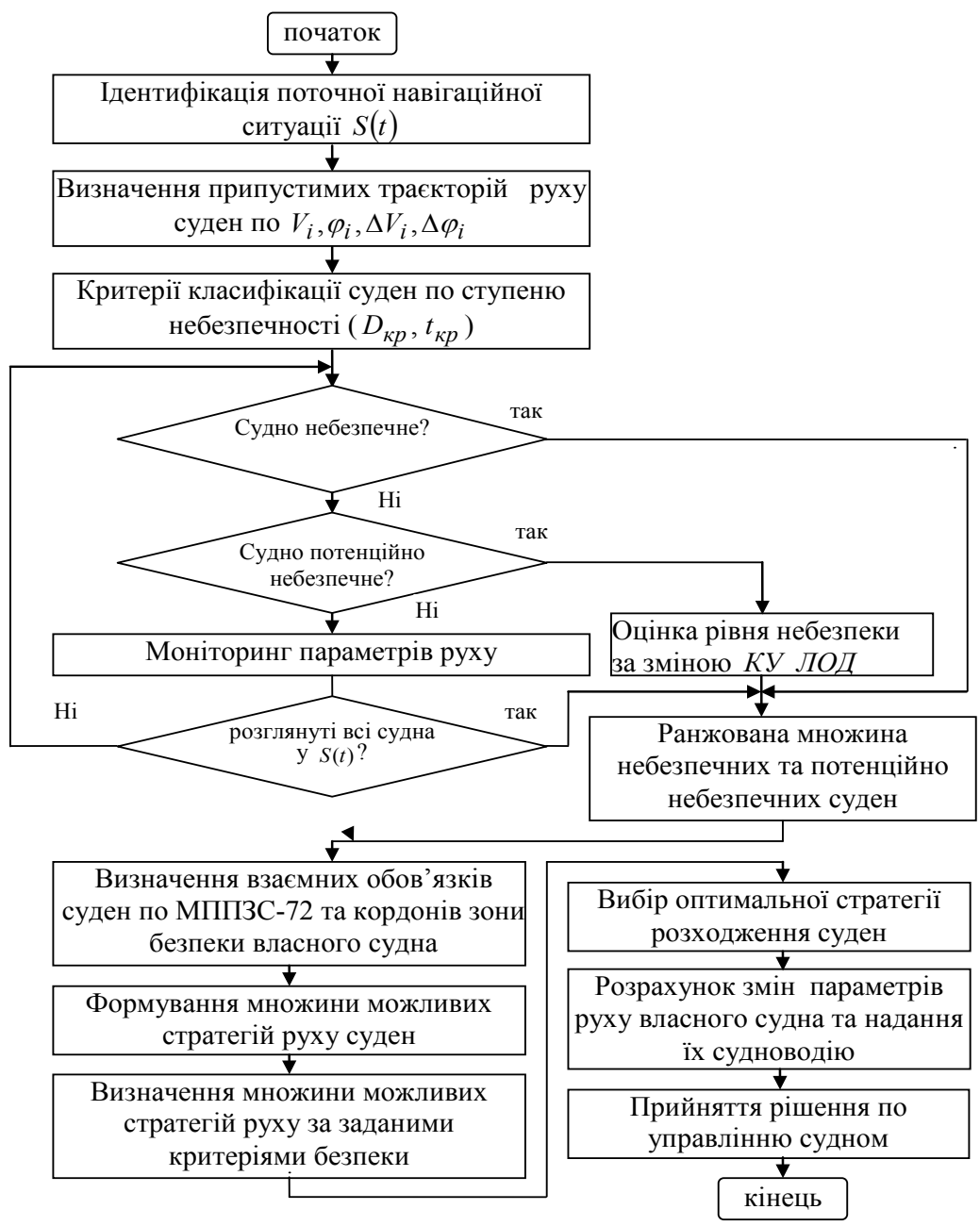

Рис. 1. Алгоритм роботи СППР судноводія 
Судно вилучається із розгляду СППР у випадку ідентифікації його як безпечного, але моніторинг параметрів руху триває при перебуванні його в межах зони дії радіолокаційної системи (РЛС) та засобів автоматизованої радіолокаційної прокладки (ЗАРП). Для небезпечних і потенційно небезпечних суден СППР формує багатокрокову стратегію розходження на весь прогнозований період їх перебування в зоні взаємних обов'язків, з подальшою корекцією стратегії у випадку, якщо поточний розвиток ситуації буде відрізнятися від прогнозованого.

Для небезпечних і потенційно небезпечних суден СППР формує багатокрокову стратегію розходження на весь прогнозований період їхнього перебування у зоні взаємних обов'язків, із подальшою корекцією стратегії у випадку, якщо поточний розвиток ситуації буде відрізнятися від прогнозованого. У процесі формування стратегії розходження враховується передбачувана зміна параметрів руху суден, обумовлена їх взаємодією один з одним відповідно до МППЗС-72.

\section{5. База даних (БД) СППР судноводія}

Створення СППР судноводія потребує розробки відповідних моделей та методів накопичення і обробки навігаційних даних.

Використання класичних методів штучного інтелекту ускладнюється тим, що більшість 3 них або жорстко детерміновані і не дозволяють якісно вирішити завдання за наявності суперечливості чи неповноти вихідних даних (продукційні системи, теорія ігор, семантичні мережі) або не забезпечують достатньої надійності одержуваного рішення (нечітка логіка, нейронні мережі, байєсовські мережі), або мають високу складність практичної реалізації і не задовольняють тимчасовим обмеженням (генетичні алгоритми, переборні методи, методи евристичного пошуку). Зазначені обставини, а також необхідність застосування досить простих у практичній реалізації механізмів самонавчання СППР, зумовили доцільність використання прецедентних (CBR або Case-Based Reasoning) методів. CBR, або метод міркування на основі прецедентів, є одним з напрямків у дослідженнях зі штучного інтелекту, що інтенсивно розвиваються [5, с. 494].

Найбільш складним етапом роботи прецедентної СППР є етап класифікації поточної ситуації. В якості методу, за допомогою якого здійснюється обчислення заходів подібності прецедентів, використовується 
метод пошуку найближчого сусіда, в основі якого лежить спосіб вимірювання ступеню збігу значень атрибутів, які визначають прецедент.

Атрибутами $є$ тип маневру і параметри руху судна. Як тільки поточна ситуація ідентифікована, судноводій може прийняти рішення iз запропонованих системою альтернатив на основі вже наявних (збережених) прецедентів, або самостійно. Вибір найбільш відповідного конкретній ситуації прецеденту, дозволяє сформувати на його основі рішення в готовому вигляді, або вимагає проведення додаткових дій 3 адаптації рішення з метою врахування відмінностей у характеристиках сформованої і базової ситуації. Якщо відповідний прецедент невиявлений або процес адаптації вимагає залучення додаткової інформації, прийняття рішення потребує звернення до бази знань СППР, що містить основні відомості про предметну область і застосування для прийняття рішення згідно особистого досвіду судноводія. В останньому випадку відбувається формування нового прецеденту, який зберігається в СППР. Ситуація, для якої був збережений прецедент, надалі вважається опорною або базовою.

Процес функціонування прецедентної СППР можна представити у вигляді CBR-циклу (рис. 2), що складається з чотирьох основних фаз:

1) отримання (вибір) з БД СППР найбільш доречного прецеденту чи множини прецедентів, на основі заданого відношення подоби;

2) використання обраних прецедентів для прийняття рішення;

3) перегляд і корекція (адаптація), які у разі необхідності приймалися раніше, в обраних прецедентах рішень;

4) збереження в БД прийнятого рішення і сформованої ситуації в якості нового прецеденту чи відповідна зміна обраного прецеденту, що може бути корисним в подальшому при вирішенні аналогічних завдань.

Головною особливістю CBR-циклу є те, що його застосовують при безпосередній взаємодії з особою, яка приймає рішення, що забезпечує процес самонавчання СППР.

Оскільки СППР судноводія функціонує в режимі реального часу, це накладає жорсткі часові обмеження на процеси вироблення та прийняття рішень і вимагає побудови сценаріїв розходження суден на весь період взаємодії. Аналіз низки зарубіжних та вітчизняних робіт, присвячених теорії і практиці створення СППР в судноводінні [6, с. 140; 7, с. 41], показує, що найважливішим чинником, який необхідно врахо- 


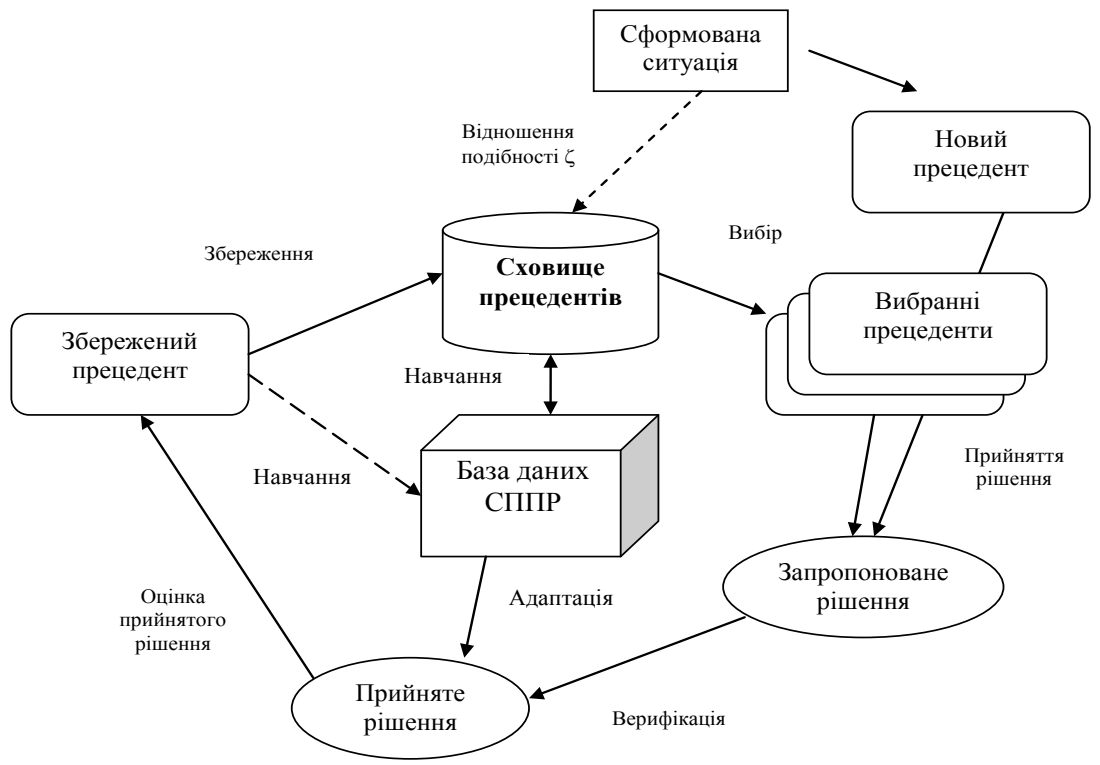

\section{Рис. 2. Фази CBR-циклу}

вувати при описі процесу розходження суден, $є$ характер їх взаємодії. При цьому необхідно враховувати принцип спільності інтересів взаємодіючих суден, що складається в уникненні зіткнення і нормативну координацію їх поведінки відповідно МППЗС-72.

Застосування запропонованого підходу до формалізації правил МППЗС-72 дозволило реалізувати в СППР імітаційну модель розходження суден, що враховує вимоги МППЗС-72 і логіку дій судноводіїв.

Для подальшого уточнення сценаріїв розвитку навігаційних ситуацій в СППР здійснюється оцінка параметрів руху суден, на підставі якого відбувається прогнозування можливих траєкторій їх руху з метою обмеження кількості можливих сценаріїв розходження, що підлягають аналізу.

\section{6. Підтримка прийняття рішень при розходженні суден}

Для надійної роботи СППР судноводія перш за все необхідно зменшити кількість інформації, яка повинна бути прийнята до обробки. При розходженні двох суден існує 288 ситуацій розходження і видів 
маневрування. При 20 суднах число ситуацій і маневрів взаємного розходження становить 54720 [8, с. 68]. Таку велику кількість інформації судноводій не може обробити, і йому потрібна допомога в підтримці принципового рішення по маневруванню, що формує СППР.

Спочатку наявна навігаційна ситуація підлягає обробці в модулі ситуаційного аналізу, який за даними автоматичної ідентифікаційної системи (AIC) розраховує відстань до всіх суден у вигляді матриці, і відкидає 3 подальшої обробки ті, відстань до яких збільшується. Як показує виконаний нами аналіз, в більшості випадків число таких суден досягає $50 \%$.

Другим кроком $є$ аналіз характеру зміни відносного руху за трьома факторами:

- розташування інших суден щодо діаметральної площині власного - праворуч або ліворуч;

- величиною кута між ЛВР і діаметральною площиною свого судна, курсового кута ЛВР $-\alpha<900, \alpha=90^{\circ}, \alpha>90^{\circ}$;

- відносним курсом між лінією діаметральної площині власного та іншого судна, $\mathrm{P}<900, \mathrm{P}=90^{\circ}, \mathrm{P}>90^{\circ}$, - перетинає курс по носу, проходить через нас або перетинає лінію курсу по кормі.

На підставі аналізу існуючих залежностей був розроблений аналізатор ситуації зближення, аналізатори вибору виду маневру і розрахункові схеми визначення часу і відстані до інших суден, в момент початку маневрування власного.

Він складається з блоку розрахунку відстані до всіх суден, які постійні за даними AIC, визначає дистанцію і формує матрицю дистанцій. Позначимо кількість спостережуваних суден через n. Параметри, виміряні від власного судна на інші, будемо позначати індексом нуль і цифрою, яка позначає інше судно в межах $i \in[1, n]$, а між суднами, що спостерігаються - індексом 3 двома цифрами, першою з яких вимірюється пеленг і дистанція, а другою - на яке судно. Таким чином можна аналізувати i оцінювати ситуацію зближення між суднами в берегових системах.

СППР аналізує різницю подальшої і попередньої дистанції через інтервал часу $1 \div 3$ с. Якщо $D\left(t_{i+1}\right)-D\left(t_{i}\right)>0$ то таке судно знімається 3 подальшої обробки, зберігаючи аналіз дистанції в подальшому.

Важливою функцією СППР є підтримка прийняття рішень судноводія при надмірному, небезпечному та аварійному зближенню суден і вибору маневру власного судна в цих випадках. 
Для вирішення зазначеної задачі були розроблені розрахункові схеми і алгоритми, які містять вперше запропоновані способи і методики функціонування системи управління судном і контролю над процесом переміщення та зближення, включаючи оцінку надмірного і небезпечного зближення, а також вибір маневру для попередження аварійної ситуації на підставі даних АIC.

Для вирішення завдання введемо дві аксіоми, які очевидні і не вимагають доказів:

Аксіома 1. Якщо існує ймовірність зіткнення, то ці цілі небезпечні і виконується умова $(d \Pi / d t)=0,(d D / d t)<0$. (курс не змінюється, дистанція зменшується).

Аксіома 2. Оптимальним курсом відвороту для попередження зіткнення $є$ паралельний або контркурс небезпечного судна.

Алгоритм вибору виду маневру полягає у розрахунку відстані між суднами і часі настання ситуації останнього моменту з урахуванням геометрії зближення, параметрів руху цілей і власного судна, його маневрених характеристик і цілей для всіх альтернатив виконання i тієї, яка настає останньою. Момент надмірного зближення вважатимемо, коли спочатку у розпорядженні судноводія є три можливості попередити зіткнення: гальмування заднім повним ходом; перекладанням керма вліво або вправо на борт. При цьому будемо вважати «маневром останнього моменту» той, який настане останнім.

Науково-методологічні основи підготовки інформації для команди містка про критичні й аварійні ситуації і представлення ії̈ визначено модельним курсом IMO 1.22 «Судновий тренажер і робота в колективі містка» [9, с. 7], що дозволяє завчасно прийняти рішення для його попередження. Однак зазначений модельний курс не містить алгоритмів і програм організації містка при виникненні аварійної ситуації. Крім того в ньому не міститься обгрунтування ефективних способів формування стійкого навику оператора судна.

Обчислення за кожною розрахунковою схемою для заданої ситуації зближення закінчуються візуалізацією часу і дистанції до небезпечного судна в момент надмірного, небезпечного і аварійного зближення. При цьому інформація про аварійне зближення є передісторією аварійної ситуації.

Аналізатор визначає розрахункову схему зближення, формує іiї візуалізацію і виконує розрахунок відстані до небезпечного судна і часу 
віддачі відповідної команди з управління власним судном для попередження аварійного зближення.

При цьому завжди першою настає ситуація надмірного зближення, коли у розпорядженні судноводія $є$ ще дві альтернативи попередження зіткнення. Наступною є ситуація небезпечного зближення, коли в розпорядженні судноводія є ще один маневр. При настанні третьої останньої можливості попередити зіткнення, настає ситуація аварійного зближення, в модулі візуалізації СППР судноводія видається рекомендація про вид маневру і спрацьовує звукова сигналізація. Якщо судноводій пропустив цей момент, то необхідно виконувати маневр останнього моменту і дати машині команду працювати заднім повним ходом, для зменшення пошкоджень при зіткненні.

Запропонована нами модель уникнення зіткнень суден відрізняється від існуючих [10, с. 71] тим, що містить спосіб визначення меж надмірним, небезпечним або аварійним зближенням суден в СППР судноводія та забезпечує вибір режимів розходження суден в залежності від навігаційної ситуації, що склалася.

\section{7. Розробка прототипу СППР судноводія}

Розроблена СППР судноводія включає в себе окремі програмні модулі, що забезпечують вирішення задач розходження та маневрування судна відповідно.

Програмний модуль «Тrajectory» здійснює пошук безпечної траєкторії руху с урахуванням низки факторів: кількість зустрічних суден, що спостерігаються на поточний момент часу, наявність серед них небезпечних, властивостей руху власного судна, параметрів руху небезпечних суден, їх відносного розміщення відносно власного судна, правил маневрування для запобігання зіткнення.

Модуль забезпечує можливість введення параметрів руху власного судна, та параметрів навігаційної ситуації (дистанції до інших суден, їх швидкості та курси, тип видимості, час між вимірами параметрів руху інших суден, розмір «безпечної зони» судна (рис. 3).

Під час функціонування модулю здійснюється виведення правил попередження зіткнень МППЗС-72 за якими класифіковано навколишні судна та відбувалося маневрування, а також рекомендованої зміни курсу для запобігання зіткнення (рис. 4). 
Andrii Ben, Ihor Palamarchuk

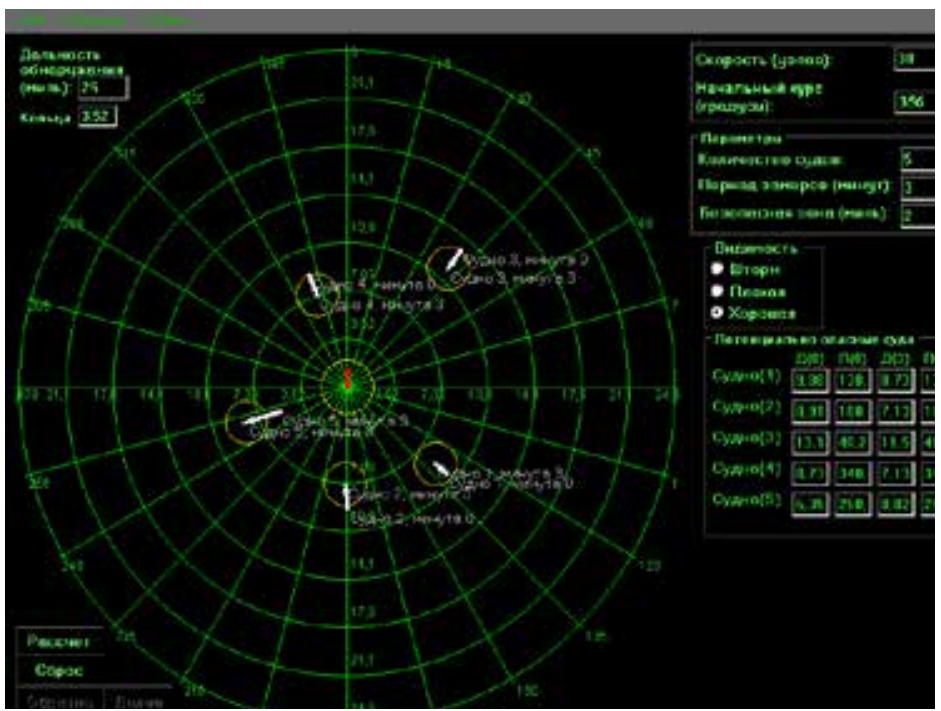

Рис. 3. Приклад аналізу навігаційної ситуації при розходженні 5-ти суден

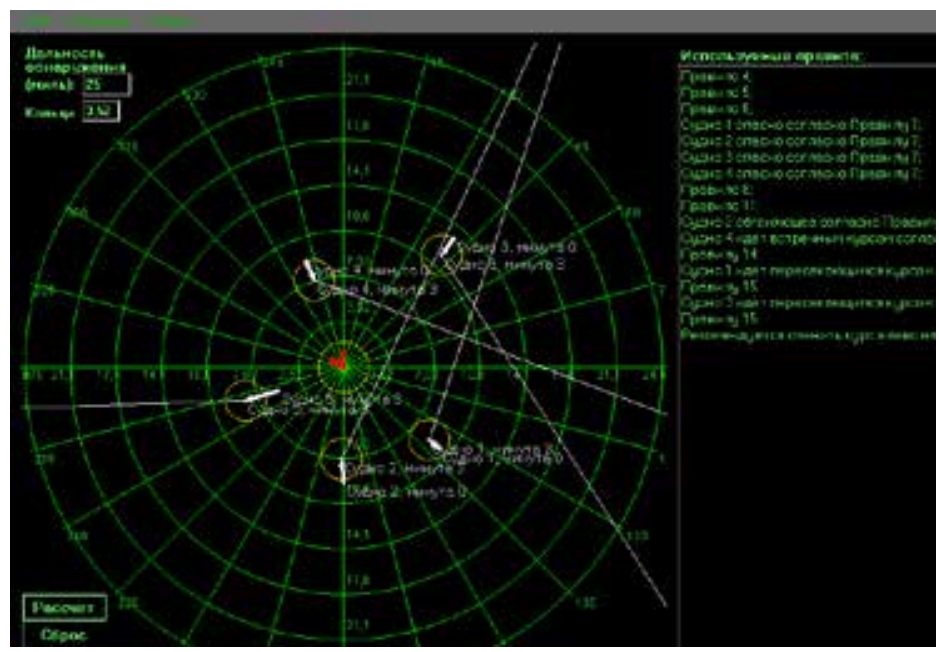

Рис. 4. Визначення СППР правил МППЗС-72, що регламентують процес розходження суден в навігаційній ситуації, що склалася 
Також здійснюється виведення візуальної інформації про маневрування суден, вектори їх курсів, графічне відображення безпечних зон власного судна та суден-цілей, їх параметри руху, та передбачувану навігаційну ситуацію, яка буде після розходження (рис. 5, 6).

Після прийняття судноводієм рішення з управління судном, прийняте рішення та поточна навігаційна ситуація зберігаються в БД СППР судноводія та можуть бути використані в майбутньому при виникненні аналогічних ситуацій з управління рухом судна.

Програмний модуль «Поворот» призначений для розрахунку полюсу повороту судна при маневруванні у вузькостях та обмеженому навігаційному просторі.

Під час розрахунків ПП СППР враховує технічні характеристики конкретного судна та навігаційні умови проведення маневрування (рисунок 7).

Тестування СППР судноводія здійснювалося в Херсонській державній морській академії із застосуванням комплексу тренажерного

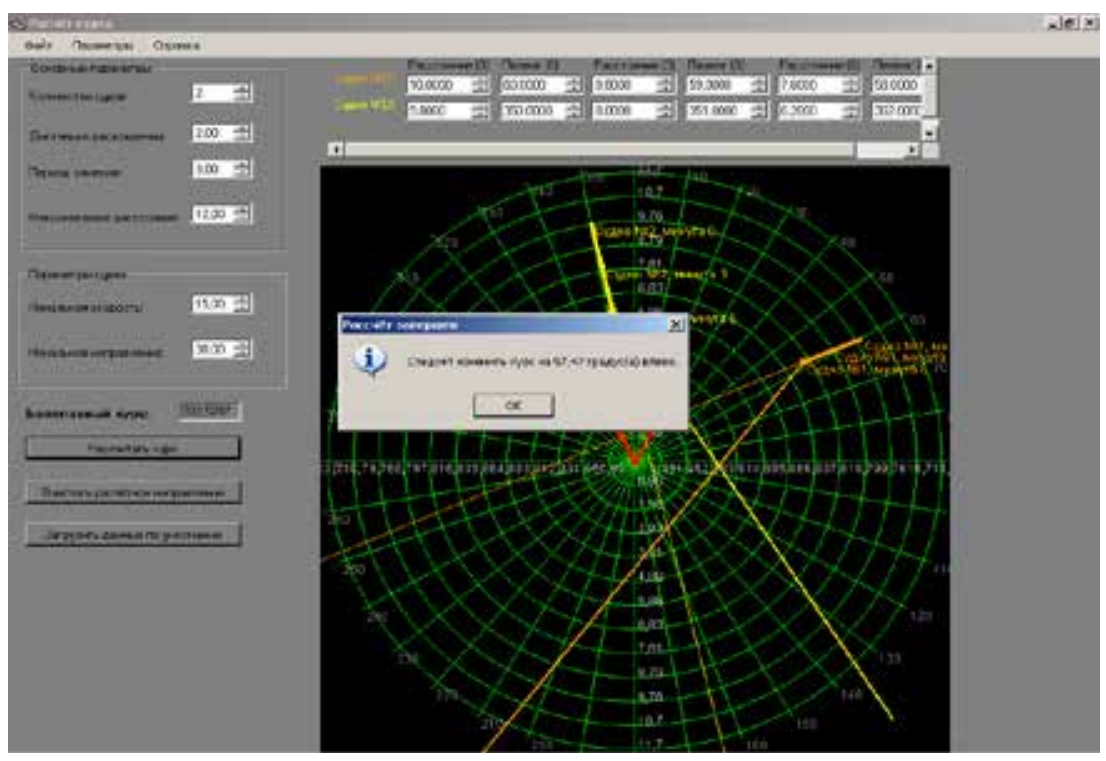

Рис. 5. Формування рекомендації СППР судноводію 


\section{Andrii Ben, Ihor Palamarchuk}

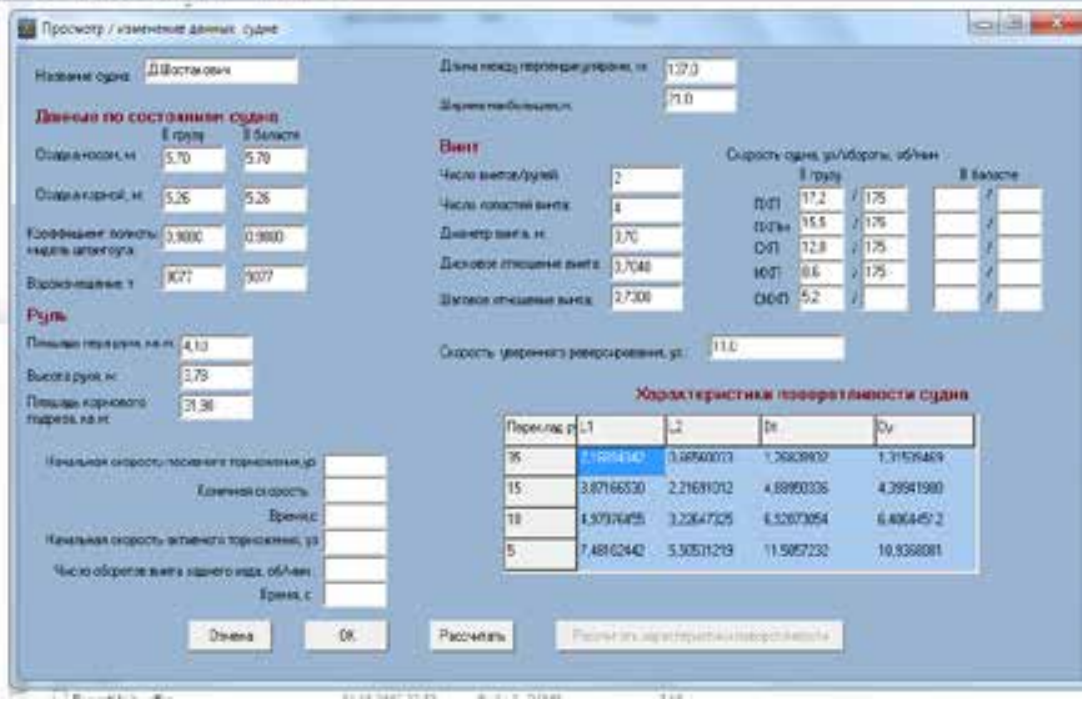

\section{Рис. 6. Програмний модуль СППР судноводія «Поворот»}

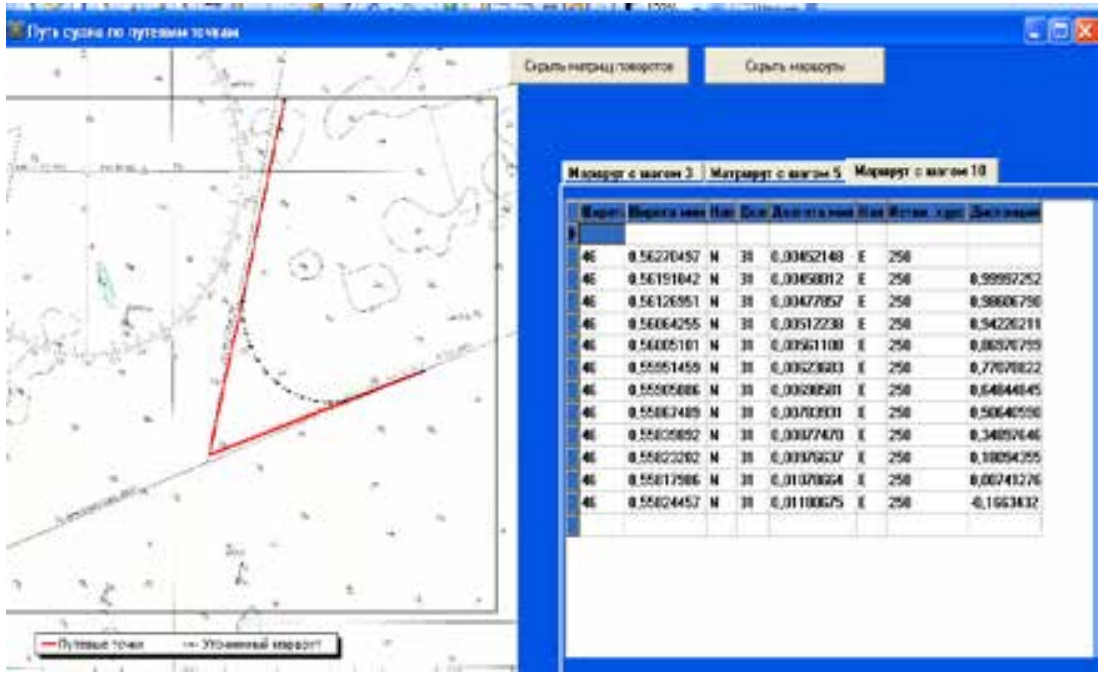

Рис. 7. Розрахунок в СППР траєкторії повороту судна 
обладнання, що здатний забезпечити якісну підготовку морських фахівців на професійному рівні. До складу лабораторно-тренажерного комплексу входять: тренажер навігаційних інформаційних систем - «ECDIS Simulator», «Full Mission Navigational Bridge» - повнофункціональний навігаційний місток, «Ship Handling and ARPA Simulator» - тренажер ЗАРП та РЛС, комплексний тренажер машинного відділення - «Engine Room Simulator», комплексний тренажер динамічного позиціонування «Full Mission Bridge DP Simulator», тренажер глобального морського зв'язку при катастрофах на морі - «GMDSS Simulator». Об'єднання нових тренажерів у єдиний комплекс дозволило створити навчально-тренажерний комплекс «Віртуальне судно».

Практична апробація прототипу СППР судноводія довела ефективність функціонування розроблених в досліджені моделей, методів та алгоритмів.

\section{8. Висновки}

Під час проведення наукового дослідження було визначено, що в умовах запровадження сучасних інформаційних технологій в судноводінні та концепції e-Navigation, найважливішою складовою підвищення безпеки сучасного судноплавства є створення СППР судноводія. При створенні таких систем необхідно враховувати, що найвагомішим чинником аварійності сучасного судноплавства, $є$ так званий «людський фактор», тому при створенні СППР судноводія особлива увага має бути приділена саме процесам взаємодії судноводія 3 технічними засобами судноводіння та шляхам зниження впливу «людського елементу» на процеси управління судном.

Показано, що в сучасних умовах впровадження СППР судноводія здатна істотно знизити аварійність сучасного судноплавства, перш за все шляхом підвищення ефективності функціонування ергатичної системи «людина - технічні засоби судноводіння» та всебічного запровадження досягнень сучасних інформаційних технологій в процеси управління судном.

Визначено, що при створенні СППР судноводія особлива увага повинна бути приділена процесам накопичення та обробки вихідних даних про навігаційні ситуації, а також методам прогнозування можливих сценаріїв та їх розвиток з урахуванням основних положень 
МППЗС-72 та принципів кооперативної взаємодії суден в умовах реального часу.

Показано, що перспективним напрямом розвитку СППР судноводія $\epsilon$ застосування методів штучного інтелекту, зокрема сценарно-прецедентного підходу до побудови бази знань СППР для моделювання процесів взаємодії учасників навігаційних ситуацій.

Розроблені теоретичні і методологічні засади побудови СППР судноводія, що враховують особливості руху суден, процесу взаємодії людини з технічними засобами судноводіння та вимоги МППЗС-72.

Під час проведення дослідження розроблено ряд нових лекційних курсів та навчальних посібників з управління рухом суден та застосування інформаційних технологій в судноводінні. Запровадження новітніх навчальних кусів та технологій підготовки фахівців в навчальний процес морських навчальних закладів дозволить істотно підвищити компетентність фахівців, знизити вплив «людського фактору» на процеси управління судном, та, як наслідок, сприятиме підвищенню безпеки сучасного судноплавства.

\section{Список літератури:}

1. Maltsev A.S. The ways of Enhancing the safety of Navigation // Thesis of the third General assembly of IAMU // Rock port, USA. 2002. Sec. II A. - P. 16-26.

2. Maltsev A.S. Five steps to assure navigational safety //Collection of IAMU scientific works. - Dalian.: Maritime University Press, 2006. - P. 170-179.

3. E-navigation: a global resource / E. Mitropoulos // Seaways. The Nautical Institute. - March 2007. - P. 7-9.

4. Мальцев А.С. Психологические аспекты маневра последнего момента / Мальцев А.С., Стариков И.М. // Судовождение: сб. научн. трудов / ОНМА. Одесса: «Латстар», 2002. Вып. 4. - С. 64-81.

5. Шерстюк В.Г. Гибридная интеллектуальная СППР для управления судном / В.Г. Шерстюк, А.П. Бень // Искусственный интеллект. - 2008. № 3. - C. 490-499.

6. Lisowski J. Game control methods in navigator decision support system / Lisowski J. // The Archives of Transport. - 2005. - No 3-4, Vol. XVII. - P. 133-147.

7. Lopez Eloy, Velasc Francisco J., Moyano Emiliano, Rueda Teresa M. - Fullscale manoeuvering trials simulation, Journal of Maritime Research, Vol. I. No. 3, 2004, pp. 37-50.

8. Мальцев А.С. Обобщенный критерий оценки согласованности системы управления и характеристик человека-оператора / А.С. Мальцев, В.В. Голиков, Д.С. Жуков // Вісник Одеського національного морського університету : зб. наук. праць. - Вип. 24. - Одеса: ОНМУ, 2008. - С. 65-75. 
9. IMO SUB-COMMITTEE ON SAFETY OF NAVIGATION. 58th session. Agenda item 6. NAV 58/WP.6/Rev.l. - E-NAVIGATION. - July 2012.

10. Lisowski J. Mathematical modeling of a safe ship optimal control process / Lisowski J. // Polish Journal of Environmental Studies. - 2005. - Vol. 14. - P. 68-75.

\section{References:}

1. Maltsev A.S. The ways of Enhancing the safety of Navigation// Thesis of the third General assembly of IAMU // Rock port, USA.2002. Sec. II A. - P. 16-26.

2. Maltsev A.S. Five steps to assure navigational safety.//Collection of IAMU scientific works. - Dalian.: Maritime University Press, 2006. - P. 170-179.

3. E-navigation: a global resource / E. Mitropoulos // Seaways. The Nautical Institute. - March 2007. - P. 7-9.

4. Mal'cev A.S. Psihologicheskie aspekty manevra poslednego momenta / Mal'cev A.S., Starikov I.M. // Sudovozhdenie: sb. nauchn. trudov / OHMA. Odessa: «Latstar», 2002. - Vyp. 4. - S. 64-81.

5. Sherstyuk V.G. Gibridnaya intellektual'naya SPPR dlya upravleniya sudnom / V.G. Sherstyuk, A.P. Ben' // Iskusstvennyj intellekt. - 2008. - № 3. S. 490-499.

6. Lisowski J. Game control methods in navigator decision support system / Lisowski J. // The Archives of Transport. - 2005. - No 3-4, Vol. XVII. - P. 133-147.

7. Lopez Eloy, Velasc Francisco J., Moyano Emiliano, Rueda Teresa M. Full-scale manoeuvering trials simulation, Journal of Maritime Research, Vol. I. No. 3, 2004, pp. 37-50.

8. Mal'cev A.S. Obobshchennyj kriterij ocenki soglasovannosti sistemy upravleniya i harakteristik cheloveka-operatora / A.S. Mal'cev, V.V. Golikov, D.S. Zhukov // Visnik Odeskogo nacionalnogo morskogo universitetu: zb. nauk. prac'. - Vip. 24. - Odesa: ONMU, 2008. - S. 65-75.

9. IMO SUB-COMMITTEE ON SAFETY OF NAVIGATION. 58th session. Agenda item 6. NAV 58/WP.6/Rev.l. - E-NAVIGATION. - July 2012.

10. Lisowski J. Mathematical modeling of a safe ship optimal control process / Lisowski J. // Polish Journal of Environmental Studies. - 2005. - Vol. 14. - P. 68-75. 